\title{
VAGINISMUS SEBAGAI ALASAN PERCERAIAN MENURUT KOMPILASI HUKUM ISLAM DAN FIQH SYAFI'IYAH
}

\author{
Nurhayati Zein \\ Fakultas Tarbiyah dan Ilmu Keguruan UIN Suska Riau \\ E-mail: nurmeicil@yahoo.com
}

\begin{abstract}
Vaginismus is a disease or disparity in the form of muscle spastic around vagina mouth, resulting the vagina closed so that it is possible to do sexual intercourse. This article discusses, can vaginismus as the reason for divorce. There is no direct mention in Fikih Syafi'yah and in the Compilation of Islamic Law that virginismus can be as a reason for divorce. Both only satate that one of the reason for divorce is if one gets handicap or disease so that cannot do the duty as wife or husband. Marriage is a tying claiming the existence of execution of rights and obligations between wife and husband. The wife who has virginismus can not do her duty to do sexual intercourse with the husband. Thereby, vaginismus can be take as a reason for divorce.
\end{abstract}

Kata Kunci: vaginismus, KHI, hubungan suami sitri, perceraian, Syafi'iyah

\section{PENDAHULUAN}

Perkawinan adalah ikatan yang suci dan sakral antara seorang lakilaki dan perempuan. Lembaga ini merupakan sarana yang paling aman dan efektif untuk mengendalikan keinginan biologis manusia, dan ini juga 
merupakan pembeda antara manusia dengan hewan. Disamping itu, secara sederhana, perkawinan juga bermaksud mengembangkan keturunan dan meneruskan kehidupan dan masa depan umat manusia. Oleh sebab itu, perkawinan merupakan salah satu dari sunnatullah, sebagaimana diungkapkan dalam firman Allah SWT dalam Surat An-Nur ayat 32:

ö/ä.Ï \$t6Ï̃̃ ôÏ̈ tûüÅsî=»đÁ9\$\#ur óOä3ZÏB 4 yJ»t F\{\$\# (\#qßsÅ3Rr\&ur “ÏB a !\$\# ãNÎgÏYøóã uä!\#t s)èù (\#qçRqä3t bÎ) 4 öNà6Í $\neg$ !\$tBÎ)ur

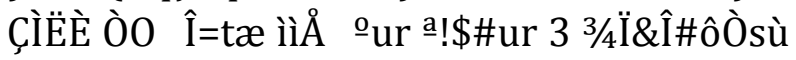
Artinya: Dan kawinkanlah orang-orang yang sedirian diantara kamu, dan orangorang yang layak (berkawin) dari hamba-hamba sahayamu yang lelaki dan hamba-hamba sahayamu yang perempuan. jika mereka miskin Allah akan memampukan mereka dengan kurnia-Nya. dan Allah Maha luas (pemberian-Nya) lagi Maha Mengetahui.

Dari ayat di atas tergambar bahwa Allah SWT. menganjurkan kepada setiap orang yang telah mempunyai kemampuan untuk melaksanakan perkawinan. Hal ini juga dikuatkan dengan hadis yang diriwayatkan dari Anas bin Malik bahwa Nabi Muhammad Saw. memuji Allah SWT dan Anas melihatnya, dan beliau bersabda: "akan tetapi aku sholat, tidur, puasa, berbuka dan aku menikahi perempuan, maka siapa yang membenci sunnahku maka ia bukan dari golonganku." (Muttafaqun Alaih).

Allah SWT mengatur kehidupan manusia dengan berbagai hukum yang termuat dalam Al-Qur'an dan Hadis. Khususnya aturan tentang hubungan antara laki-laki dan perempuan karena mereka dikaruniai Allah dengan nafsu seks yang membutuhkan pelampiasan. Perkawinan adalah cara terbaik untuk menyalurkan libido seksual antara laki-laki dan perempuan. Dengan perkawinan keduanya telah terikat dengan kewajiban saling memberi nafkah bathin kepada pasangannya.

Oleh karena itu, salah satu tujuan perkawinan adalah menghalalkan hubungan seksual antara suami istri, ${ }^{1}$ sehingga masalah seksual tidak dapat dipisahkan dengan kebahagiaan yang akan dicapai. Perkawinan yang tidak dilandasi dengan hubungan seksual yang nyaman bisa mengakibatkan terjadinya keretakan hubungan. Kebutuhan seks yang tidak terpenuhi dapat mempengaruhi pikiran bagi pasangan suami istri yang selanjutnya dapat pula menyebabkan terjadinya dwifungsi orgasme, dyispereunia dan vaginismus. ${ }^{2}$ Vaginismus adalah istilah medis untuk kejang atau kontraksi otot di sekitar vagina yang membuat hubungan seks sulit dan sangat menyakitkan, atau malah tidak mungkin terjadi. ${ }^{3}$

Kejang otot atau vaginismus bisa terjadi pada waktu atau akan melakukan hubungan senggama, yang bisa mengakibatkan tidak 
mungkin untuk melakukan hubungan tersebut. Hal ini disebabkan karena lubang vagina yang menyempit dan bisa menghilangkan rasa rangsangan yang dilakukan sebelumnya.

Marzuki Umar Sa'bah menyebutkan bahwa peristiwa kontraksi, penegangan atau pengerasan akan datang tiba-tiba ketika penis melakukan penetresi, yaitu pada bagian distal vagina. Kejadian ini bisa terjadi ketika penis masuk. Jika pegangan ini sangat kuat bisa jadi penis yang masuk akan terjepit dengan kuat sehingga tidak dapat keluar dari vagina. ${ }^{4}$

Gangguan seks yang terjadi antara suami istri dapat menimbulkan penderitaan, pertengkaran, pisah ranjang, bahkan dapat terjadi perceraian. Pada hal tujuan utama perkawinan adalah mewujudkan rumah tangga yang mawaddah dan rahmah.

Islam mengatur masalah perkawinan dengan lengkap, bahkan jika hubungan rumah tangga tidak bisa dipertahankan maka jalan terakhir adalah perceraian. Perceraian yang dibenarkan dalam Islam mestilah memiliki sebab dan alasan yang tepat. Karena Allah SWT sangat benci terhadap perceraian, sebagaimana diungkapkan dalam hadis yang diriwayatkan dari Ibnu Umar bahwa Rasulullah bersabda: "Di antara sesuatu yang halal tetapi dibenci Allah SWT. adalah thalak." (Diriwayatkan oleh Abu Daud, Ibnu Majah dan disyahkan oleh Hakim, dan Abu hatim menguatkan kemursalannya).

Di Indonesia, Kompilasi Hukum Islam (KHI) merupakan salah satu rujukan para hakim Pengadilan Agama untuk memutuskan perkara perdata umat Islam, termasuk masalah yang berkaitan dengan perkawinan dan perceraian. Diantara alasan perceraian yang diakui dalam Kompilasi Hukum Islam tercantum dalam pasal 116 poin (e) yaitu: "Salah satu pihak mendapat cacat badan atau penyakit dengan akibat tidak dapat menjalankan kewajibannya sebagai suami istri."5

Dalam hal ini, ulama Syafi'iyah berpendapat bahwa masingmasing pihak dari suami istri mempunyai hak khiyar dengan sebab aib yang mungkin terjadi antara keduanya, misalnya gila, kusta, dan supak. Suami mempunyai hak fasakh apabila ia mendapatkan istrinya mempunyai alat kelamin yang tidak berfungsi. Dan istri mempunyai hak fasakh jika mendapatkan suaminya majbub atau impoten. ${ }^{6}$

Dalam Hasyi'ah al-Bajuri'Ala Ibnu Qasim al-Ghazali diterangkan bahwa "sebab terjadinya khiyar dalam pernikahan antara suami istri adalah gila, sakit lepra atau kusta. Sedangkan (tumbuhnya daging pada vagina) dan (adanya tulang pada vagina) khusus terjadi pada istri. (terpotongnya seluruh zakar atau sebahagiannya) dan (lemahnya suami 
untuk menggauli istri) karena lemah kejiwaan atau fisiknya, hal ini khusus bagi suami. ${ }^{7}$ Dalam penetapan khiyar tidak ada perbedaan apakah aib tersebut terjadi sebelum akad atau terjadi sesudah akad dan sebelum atau sesudah dukhul.

Dalam Kompilasi Hukum Islam atau fiqh Syafi'iyah tidak ditemukan vaginismus sebagai salah satu alasan perceraian. Apabila keadaan istri vaginismus maka suami tidak dapat menyalurkan seksnya secara normal.

Dari penjelasan di atas terlihat bahwa dalam KHI dan fiqh Syafi'iyah tidak ditemukan vaginismus secara tegas sebagai alasan sebagai salah satu alasan perceraian. Tetapi baik KHI maupun fiqh Syafi'iyah sama-sama menyebutkan ada penyakit yang bisa dijadikan alasan mengajukan perceraian. Apakah vaginismus dapat dimasukkan dalam kategori penyakit yang tertera pada poin (e) KHI pasal 116 seperti disebutkan di atas dan bagaimana pula halnya dalam kajian fiqh Syafi'iyah, apakah dapat diqiyaskan kepada rataq (رنق ) dan qaran (قرن ) dengan illat terhalangnya melakukan persetubuhan sebagai alasan suami menceraikan istrinya.

\section{PEMBAHASAN}

\section{Pengertian Vaginismus}

Kamus Penuntun Populer Bahasa Kedokteran menyatakan bahwa vaginismus adalah suatu kekejangan otot di sekitar vagina yang menimbulkan rasa sakit. ${ }^{8}$ Abu Zakaria mendefenisikan ${ }^{9}$ vaginismus sebagai salah satu bentuk gangguan seksual berupa kejang di sekitar mulut vagina. Koesnadi ${ }^{10}$ menjelaskan bahwa vaginismus merupakan suatu kelainan atau penyakit di mana wanita mengalami kontraksi spatial (kram/kejang) pada bagian sepertiga luar dari liang senggama pada waktu dilakukan atau akan dilakukan persenggamaan. Sedangkan menurut Ibnu M. Rasyid ${ }^{11}$ vaginismus adalah bentuk gangguan seksual bagi wanita berupa kejang-kejang otot di sekitar mulut vagina yang disebut kejang "genetikal." Budi Handrinto dan Nana Mintarti ${ }^{12}$ mengungkapkan bahwa vaginismus disertai dengan otot-otot paha dan vagina dalam keadaan mengkerut dan kaku sehingga tidak bisa melakukan hubungan seksual, disertai dengan kejang-kejang di sekitar mulut vagina yang meliputi sepertiga bagian distal vagina. Keadaan ini terjadi secara spontan tanpa disadari.

Marzuki Umar Sa'bah dalam bukunya Sex dan Kita ${ }^{13}$ mengungkapkan bahwa vaginismus adalah peristiwa kontraksi atau peregangan dan pengerasan yang datang tiba-tiba ketika penis melakukan 
penetrasi yaitu pada bagian distal vagina (bagian yang bentuknya tidak rata).

Dari beberapa defenisi di atas pada dasarnya tidak terdapat perbedaan yang prinsipil, hanya saja terdapat variasi dalam pengungkapannya. Maka dapat disimpulkan bahwa vaginismus merupakan kelainan seks atau penyakit yang datang tiba-tiba tanpa disadari, ditandai dengan kekejangan otot di sekitar vagina (pada bagian sepertiga luar liang senggama) yang mengganggu masuknya penis ke dalam vagina sehingga persetubuhan sukar dilaksanakan.

\section{Sebab-sebab Vaginismus}

Terdapat beberapa penyebab terjadinya vaginismus sebagaimana yang dipaparkan oleh beberapa ahli. Koesnadi mengemukakan penyebab vaginismus pada wanita antara lain; ${ }^{14}$ (a) Kefanatikan terhadap paham bahwa "seks itu kotor dan dosa", (b) Pernah mengalami pengalaman pahit dalam kejahatan seksual (misalnya perkosaan dan lainnya), (c) Adanya kelainan dalam alat kelamin yang dapat menyebabkan rasa sakit waktu hubungan seksual, (d) Homoseksual /lesbian.

Naek L. Tobing menyatakan bahwa penyebab vaginismus adalah: ${ }^{15}$ (a) Ketakutan gadis karena mendengar cerita bahwa akan koyak dan berdarahnya selaput darah dan hal ini akan menimbulkan rasa sakit, (b) Penderita mengalami infeksi vagina, (c) Kurang pengetahuan tentang seks dan menganggap bahwa seks adalah hal yang tabu sehingga tidak perlu untuk dipelajari dan diketahui, (d) Emosional, (e) Fobianya seorang wanita terhadap hubungan seks, (f) Kelainan dalam bentuk bawaan dari vagina.

Menurut Marzuki Umar Sa'bah, ${ }^{16}$ sebab-sebab terjadinya vaginismus diungkapkan berdasarkan macam-macam dari vaginismus itu sendiri, yaitu: (a) Vaginismus refleksi primer, disebabkan tidak koyaknya selaput dara pada waktu pertama kali melakukan senggama; (b) Vaginismus refleksi sekunder, yaitu pada wanita yang pernah mampu melakukan senggama disebabkan oleh kelainan organis atau somatic; (c) Vaginismus psikogen primer, yaitu yang terjadi pada senggama pertama di mana wanita mengalami tekanan psikis, misalnya ketakutan, kecemasan hebat dan rasa berdosa; (d) Vaginismus psikogen sekunder, yaitu kondisi pada wanita yang sebelumnya mampu melakukan senggama, tetapi setelah beberapa waktu muncul gejala vaginismus. Ini disebabkan oleh penolakan senggama secara sadar atau tidak karena ketidaksukaan kepada partner seksnya. 
Budi Hendrianto dan Nana Mintarti menyebutkan dua factor penyebab terjadinya vaginismus yaitu: ${ }^{17}$ (a) Faktor fisik. Misalnya terjadi kelainan pada alat kelamin sehingga ketika terjadi coitus terasa sangat nyeri dan terjadi kejang-kejang; (b) Faktor psikis. Misalnya pengalaman tertentu pada masa lalu yang menyebabkan perasaan sangat trauma untuk hubungan seksual.

Lebih lanjut Abu Zakaria menerangkan bahwa vaginismus dapat disebabkan oleh factor jasmaniah dan rohaniah.18 Faktor jasmaniah, misalnya adanya kelainan pada alat kelamin yang bisa menyebabkan coitus menjadi nyeri yang menyebabkan kejang otot-otot. Faktor rohaniah, misalnya terjadinya kecemasan-kecemasan tertentu, rintangan seksual kuat yang terjadi pada masa kanak-kanak, pengalaman seksual yang mengecewakan pada masa lampau dan segala faktor lainnya yang bisa menimbulkan kekejangan otot vagina.

Penyebab vaginismus menurut Ibnu M. Rasyid, hampir sama dengan yang diungkapkan oleh Abu Zakaria, adalah karena adanya pengaruh factor-faktor jasmaniah dan factor rohaniah. Faktor jasmaniah misalnya karena memang ada kelainan dalam vagina itu, sehingga kalau melakukan senggama faraj menjadi nyeri sehingga otot-otot di sekitar vagina menjadi kejang. Sedangkan faktor rohaniah misalnya kecemasan tertentu, kisah-kisah yang mengerikan tentang orang yang melakukan senggama yang didengarnya sewaktu masih kecil. Adanya pengalaman seksual yang mengecewakan pada masa lampau seperti akibat perkosaan atau pemaksaan yang benar-benar menimbulkan rasa takut terhadap kehidupan seksual. ${ }^{19}$

Menurut Lilian Yuwono, penyebab vaginismus adalah; (a) Faktor fisik seperti penebalan hymen yang menimbulkan kejang; (b) Fobia; (c) Pemeriksaan geneokologis yang kurang tepat dan luka selama persalinan atau perkosaan seks yang menimbulkan rasa sakit pada vagina sehingga usaha di masa medatang untuk melakukan penetrasi akan membuatnya menjadi cemas dan menimbulkan kejang vagina; (d) Ketakutan berkembang menjadi wanita seutuhnya; (e) Karena penderitaan waktu hamil dan melahirkan ${ }^{20}$

Berdasarkan beberapa uraian di atas dapat disimpulkan bahwa terjadinya vaginismus disebabkan oleh factor fisik dan faktor psikologis. Faktor fisik yang menyebabkan vaginismus adalah adanya kelainan dalam alat kelamin yang menyebabkan rasa sakit waktu hubungan seks dilakukan, kelainan bawaan pada vagina, penebalan hymen yang menimbulkan kejang, dan infeksi dari genetalia. Faktor Psikologis yang menyebabkan vaginismus meliputi kefanatikan terhadap paham bahwa 
seks itu "dosa dan kotor" dikarenakan pendidikan keliru dari masa kecil, penderitaan waktu hamil dan melahirkan, pengalaman pahit dalam kejahatan seksual, ketakutan berkembang menjadi wanita seutuhnya karena wanita tetap mempertahankan ikatan dengan orang tua dan tidak menginginkan hubungan seks yang utuh, trauma pada malam pertama, dan lesbian.

\section{Akibat Vaginismus pada Perkawinan}

Seks merupakan gejolak biologis yang telah diciptakan Allah SWT. pada manusia. Hal ini dijelaskan dalam firman-Nya surat Ali Imran ayat 14:

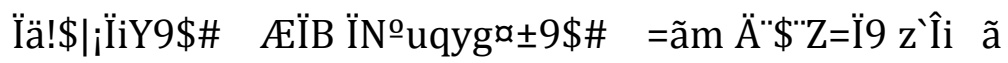
Artinya: Manusia telah dihiasi dengan cinta syahwat kepada wanita.

Untuk menyalurkan nafsu seksualnya manusia menempuh berbagai cara, baik yang dihalalkan agama maupun dengan cara yang tidak dihalalkan. Penyaluran seks yang dihalalkan agama adalah perkawinan. Dalam perkawinan suami istri bisa menyalurkan nafsu seksnya secara syah, teratur, sopan dan sehat.

Penyaluran nafsu seks kepada yang sesuai dengan tuntunan Ilahi akan membawa kepada ketenangan, ketentraman, dan rasa kasih sayang. Keadaan ini timbul dari ikatan lahir bathin antara satu sama lain. Hal ini dijelaskan Allah SWT dalam surat al-Ruum ayat 21:

\%[ํurø r\& öNä3ÅjàÿRr\& ô ÏiB /ä3s9 t,n=y\{ ‘br\& ÿ3/4ÏmÏG»t \#uä ô'ÏBur

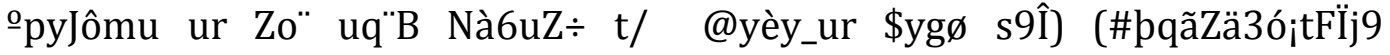
ÇËÊÈ

Artinya: Dan di antara tanda-tanda kekuasaan-Nya ialah dia menciptakan untukmu isteri-isteri dari jenismu sendiri, supaya kamu cenderung dan merasa tenteram kepadanya, dan dijadikan-Nya diantaramu rasa kasih dan sayang.

Perkawinan merupakan salah satu ibadah yang dianjurkan oleh Allah kepada makhluk yang sudah mampu untuk melakukannya. Islam memandang perkawinan sebagai ibadah yang mulia dan akan mendapatkan pahala dan manfaat-manfaat positif bagi yang melakukan sebagaimana sabda Nabi saw. yang diriwayatkan dari Yahya bin 'Uqil dari Yahya bin Umar dari Ibnu Aswad Daili dari Abizar bahwa Nabi Saw. berkata bahwa "pada setiap anggota badan salah seorang diantaramu ada sedekahnya. Para sahabat bertanya, wahai Rasulallah, apakah seseorang yang menyalurkan nafsu syahwatnya (kepada istri) akan memperleh pahala? Rasulallah menjawab, "bukankah kalian sudah mengerti, andaikata ia menyalurkan nafsu syahwatnya itu di tempat yang haram niscara ia berdosa?" 
Mereka menjawab "ya." Rasulallah bersabda: "demikian juga halnya apabila ia menyalurkan nafsu syahwatnya pada tempat yang halal, niscaya ia akan memperoleh pahala." Kemudian beliau bersabda lagi, "apakah kamu hanya memperhitungkan kejahatan tetapi tidak memperhitungkan kebaikannya." (HR. Bukhori dan Muslim) ${ }^{21}$

Dalam pandangan Islam, melakukan hubungan seksual antara suami istri adalah wajib, karena seks merupakan ekspresi cinta tertinggi dan merupakan pertemuan fisik dan emosi secara total. Penyluran seks yang memuaskan dapat membuat perkawinan menjadi bahagia, sebaliknya penyaluran seks yang tidak memuaskan dapat menghancurkan sebuah perkawinan. Apabila perkawinan tidak bahagia akan mengakibatkan kehancuran bahkan perceraian. Lestari dan tidaknya kecintaan suami istri juga ditentukan oleh normal atau tidaknya hasrat dan kemampuan seks suami istri. Oleh sebab itu, gangguan vaginismus dapat berakibat fatal bagi hubungan suami istri, baik penganten baru maupun yang sudah lama menikah. Wanita penderita vaginismus secara sadar berharap untuk melakukan coitus tetapi secara tidak sadar juga berharap untuk menghalangi penis masuk ke vagina.

Gangguan vaginismus tidak hanya melibatkan penderita (istri) saja tetapi juga berakibat bagi pasangannya. Gangguan yang diderita suami diantaranya; (a) Ganggauan psikologis. Nafsu seksual yang bergejolak harus mendapatkan penyaluran yang sempurna dan baik, dan akan membawa kepada ketenangan. Apabila layanan seksual tidak terpenuhi akan menimbulkan penderitaan kepada dua belah pihak. Suami yang tidak dapat menyalurkan nafsu seksualnya akan mengalami depresi, sering marah, susah tidur, mudah tersinggung, dan menderita penyakit psikosomatik. Suami merasa takut untuk melakukan hubungan karena berfikir akan gagal lagi, sehingga minat untuk melakukan hubungan seksual menjadi hilang22 Sebaliknya, istri yang menderita vaginismus akan merasa malu, rendah diri, frustrasi, apatis, labil, dan perasaan bersalah dan berdosa karena tidak bisa melaksanakan kewajibannya memenuhi kebutuhan bathin suami. Bahkan rasa malu, rendah diri dan bersalah akan mengakibatkan frustasi, apatis, dan labil dalam bertindak; (b) Gangguan biologis. Apabila suami memaksakan diri untuk melakukan hubungan seks dengan istri yang menderita vaginismus maka akan menimbulkan sakit yang teramat sangat bagi istri. ${ }^{23}$ Bagi suami, disebabkan vaginismus yang diderita istri, suami akan tergesa-gesa untuk melakukan hubungan seksual sehingga akan terjadi ejakulasi prematur (pengeluaran sperma yang terlampau cepat). ${ }^{24}$ 
Allah SWT menciptakan nafsu seks untuk manusia dan juga menyediakan tempat untuk menyalurkannya. Nafsu yang dimiliki mesti disalurkan secara wajar tanpa ditahan dan tanpa ada tekanan. Suami berkewajiban untuk memuaskan nafsu seks istri dan istri juga berkewajiban untuk memuaskan nafsu seks suami. Istri yang menderita vaginismus tidak sanggup untuk melakukan kewajibannya.

\section{Pandangan Kompilasi Hukum Islam terhadap Vaginismus sebagai Alasan Perceraian}

Sebagaimana dikemukakan, gangguan seks yang terjadi pada perkawinan dapat mengakibatkan tidak normalnya perjalanan rumah tangga. Oleh karena itu, vaginismus yang diderita istri merupakan gangguan fatal dalam kehidupan rumah tangga. Gangguan tersebut dapat mengakibatkan terjadinya pertengkaran dalam keluarga dan lunturnya rasa kasih dan sayang antara keduanya. Dengan demikian, tujuan perkawinan yang ingin mewujudkan keluarga yang sakinah, mawaddah wa rahmah tidak akan tercapai. Apabila keutuhan rumah tangga tidak bisa dipertahankan maka perceraian adalah akhir dari hubungan perkawinan. Dalam buku Seks dalam Islam ditemukan bahwa gangguan fungsi seksual vaginismus akan menyiksa perasaan kedua belah pihak bahkan bisa menyebabkan frustasi dan perceraian. ${ }^{25}$

Kompilasi Hukum Islam merupakan salah satu rujukan para hakim Pengadilan Agama untuk memutuskan perkara perdata umat Islam di Indonesia. Alasan-alasan perceraian yang diakui dalam Kompilasi Hukum Islam tercantum dalam pasal 116 yaitu; ${ }^{26}$ (a) Salah satu pihak berbuat zina atau menjadi pemabuk, pemadat, pejudi dan lain sebagainya yang sukar disembuhkan; (b) Salah satu pihak meninggalkan pihak lain selama dua tahun berturut-turut tanpa izin pihak lain dan tanpa alasan yang sah atau hal lain diluar kemampuannya; (c) Salah satu pihak mendapatkan hukuman penjara lima tahun atau hukuman yang lebih berat setelah perkawinan berlansung; (d) Salah satu pihak melakukan kekejaman atau penganiayaan berat yang membahayakan pihak lain; (e) Salah satu pihak mendapat cacat badan atau penyakit dengan akibat tidak dapat menjalankan kewajibannya sebagai suami istri; (f) Antara suami istri terus-menerus menjadi perselisihan dan pertengkaran dan tidak ada harapan akan hidup rukun lagi dalam rumah tangga; (g) Suami melanggar taklik talak; (h) Peralihan agama atau murtad yang mengakibatkan terjadinya ketidakrukunan dalam rumah tangga.

Dari beberapa alasan perceraian yang dibolehkan di dalam KHI di atas tidak ditemui vaginismus sebagai alasan perceraian. Namun dari 
alasan-alasan yang dibenarkan KHI tersebut dapat dipahami bahwa semua alasan kebolehan perceraian adalah hal-hal yang mendatangkan kemudharatan bagi pihak lain dan hal-hal yang mengganggu keharmonisan rumah tangga, sehingga tujuan perkawinan tidak dapat diwujudkan. Vaginismus merupakan penyakit atau gangguan seksal yang abnormal dan bisa memberikan kemudharatan kepada pihak lain sehingga untuk mewujudkan tujuan perkawinan tidak akan tercapai.

Dari fenomena tersebut tergambarlah suatu permasalahan yaitu dapatnya vaginismus dijadikan sebagai alasan perceraian oleh suami. Hal ini sesuai dengan pasal 116 Kompilasi Hukum Islam pada poin "e", yang berisikan "jika salah satu pihak mendapat cacat badan atau penyakit yang mengakibatkan tidak dapat menjalankan kewajiban sebagai suami istri sebagaimana mestinya."

Suami istri mempunyai alasan untuk bercerai apabila terdapat pada pasangannya cacat atau penyakit yang mengakibatkan tidak dapat menjalankan kewajiban sebagaimana mestinya. Dengan demikian dapatlah dimengerti bahwa vaginismus dapat dijadikan sebagai alasan perceraian, sebab istri tidak mungkin untuk melayani kebutuhan biologis suami karena terjadinya penyempitan di sekitar mulut vagina yang menghalangi hubungan seks mereka. Dengan alasan tersebut diyakini bahwa tujuan perkawinan tidak dapat tercapai jika salah satu pihak dirugikan oleh penyakit yang sulit untuk disembuhkan.

\section{Pandangan Fiqh Syafi'iyah terhadap Vaginismus sebagai Alasan Perceraian}

Perceraian merupakan perbuatan yang halal tetapi merupakan alternative terakhir bila tidak ada jalan lain yang lebih baik dari melakukannya. Menurut mazhab Syafi'i, yang diikuti oleh pengikutnya atau dikenal dengan istilah "Syafi'iyah", untuk melakukan perceraian hendaklah mempunyai alasan yang tepat, yaitu terdapatnya hal-hal yang mengganggu dan menghalangi terlaksananya hak dan kewajiban suani istri sehingga rumah tangga sakinah, mawaddah, dan rahmah tidak dapat tercapai. Tetapi dalam fiqh Syafi'iyah tidak disebutkan secara jelas tentang vaginismus yang disinyalir dapat dijadikan sebagai salah satu alasan perceraian.

Fiqh Syafi'iyah mengemukakan pendapat bahwa alasan perceraian adalah; (a) karena suami tidak sanggup memberi nafkah. Imam Asy Syafi'I menjelaskan, apabila ia (suami) tidak memperoleh nafkah untuk istrinya, maka istrinya mempunyai hak khiyar (hak memilih) antara tetap bersama suaminya atau bercerai. Jika ia memilih untuk bercerai maka itu 
dibolehkan, tapi tidak berbentuk thalaq;27 (b) Salah satu pihak berbuat zina; (c) Terjadinya pertengkaran terus-menerus antara suami istri (syiqaq); (d) Karena aib atau cacat yang menimpa salah satu pihak (suami atau istri).

Imam Syafi'i berpendapat tentang alasan perceraian sebagaimana terdapat dalam kitab Al-Umm: ${ }^{28}$

"Imam Syafi'I telah berendapat, telah mengkhabarkan kepada kami Malik dari Yahya bin Sa'id bin Musayyab bahwa ia berkata, telah berkata Umar bin Kahttab ra.: Laki-laki manapun yang menikahi seorang perempuan dan ia mendapatkan perempuan itu dalam keadaan gila, penyakit lepra dan supak, lalu suami itu menggaulinya maka bagi istri berhak mendapat mahar dan suami harus membayar denda dengan walinya. Abu Sya'tsa berkata, ada empat hal yang tidak menghambat untuk melakukan nikah, kecuali dalam keadaan gila, lepra, supak dan qaran (bertanduk). Imam Syafi'I menerangkan tentang makna qaran yaitu, sesuatu yang menjadi penghalang untuk melakukan jima' atau coitus, karena qaran tersebut tidak terdapat pada perempuan kebiasaan."

Lebih lanjut ulama Syafi'iyah menyebutkan ada beberapa alasan yang membolehkan khiyar dalam perkawinan: (a) Jika salah seorang suami istri mendapatkan pasangan dalam keadaan gila, menderita penyakit jazam (kusta) atau menderita penyakit sufak maka dibolehkan masingmasing suami istri untuk khiyar; ${ }^{29}$ (b) Masing-masing dari suami istri berhak meminta fasakh disebabkan karena adanya salah satu cacat dari cacat-cacat yang bisa terjadi pada suami istri atau pada salah satu dari keduanya; 30 (c) Seorang suami mempunyai hak fasakh jika ia mendapatkan istrinya dalam keadaan kelaminnya tertutup atau bertanduk karena ada daging yang tumbuh pada alat kelaminnya (rataq) atau ada tulang pada alat kelaminnya (qaran). ${ }^{31}$

Dari keterangan di atas dapat dipahami bahwa di dalam fiqh Syafi'iyah diantara kebolehan bagi suami untuk melakukan fasakh dalam perkawinan, salah satunya, adalah istri mengidap suatu aib atau cacat yang menyebabkan terhalangnya untuk melakukan hubungan suami istri. Hal ini sesuai dengan hadis Nabi Saw yang diriwayatkan dari Zaid bin Ka'ab bin Ujrah dari ayahnya beliau berkata: "Rasulallah Saw. mengawini 'Aliyah wanita dari Bani Ghifar. Setelah dia masuk kepada beliau dan meletakkan pakaiannya lalu beliau melihat belang putih pada sekitar bagian pinggulnya. Lalu Nabi Saw. berkata kepadanya, Pakailah pakaianmu, pulanglah engkau kepada keluargamu dan beliau suruh berikan maskawinnya." (HR. Al-Hakam) 32

Vaginismus merupakan suatu kelainan atau penyakit berupa kejang otot di sekitar mulut vagina yang mengakibatkan vagina tertutup 
sehingga tidak mungkin untuk melakukan hubungan seksual. Dari peristiwa di atas terlihat adanya unsure kesamaan antara vaginismus dengan adanya penyakit (belang putih) di sekitar pinggul istri Rasulallah Saw. yang menyebabkan dibolehkannya untuk menceraikan istri. Lebih khusus lagi, hal yang memiliki persamaan dengan vaginismus adalah penyakit daging yang tumbuh pada alat kelaminnya (rataq) atau ada tulang pada alat kelaminnya (qaran).

Dengan demikian dapatlah dipahami bahwa vaginismus juga dapat dijadikan alasan perceraian bagi suami jika suami menghendaki, karena istri yang vaginismus tidak akan dapat melayani dalam memenuhi kebutuhan biologisnya. Walaupun dalam alasan-alasan bolehnya khiyar tidak dicantumkan secara jelas mengenai vaginismus.

\section{SIMPULAN}

Perceraian dilakukan apabila tidak ada jalan lain untuk mempersatukan dan menyelamatkan keutuhan rumah tangga. Walupun perceraian merupakan perbuatan yang dihalalkan tetapi sangat dibenci Allah SWT sebagaimana sabda Nabi saw yang diriwayatkan dari Ibnu Umar ra. Bahwa Rasulullah saw. bersabda, "di antara sesuatu yang halal tetapi dibenci Allah SWT adalah thalaq." (HR. Abu Daud, Ibn. Majah dan disyahkan oleh Hakam dan Abu Hatim menguatkan kemursalannya).

Kompilasi Hukum Islam membatasi penyebab yang bisa dijadikan sebagai alasan perceraian. Pembatasan ini bertujuan agar tidak terjadi perceraian tanpa alasan sehingga merugikan pihak lain. Tetapi pada dasarnya hal-hal yang dapat dijadikan sebagai alasan adalah sesuatu yang menghalangi terwujudnya keharmonisan dalam rumah tangga. Dalam Kompilasi Hukum Islam (dalam pasal 116 pada poin " $\mathrm{e}^{\text {") }}$ dikemukakan bahwa salah satu alasan perceraian adalah apabila salah satu pihak mendapat cacat badan atau penyakit sehingga tidak dapat menjalankan kewajibannya sebagai suami atau istri. Apabila dilihat efek dari virginismus maka bisa digolongkan kepada cacat badan atau penyakit dalam pasal yang terdapat dalam Kompilasi Hukum Islam tersebut.

Fiqh Syafi'iyah, secara tersirat menggolongkan virginismus kepada salah satu alasan perceraian, yang setara dengan adanya aib atau cacat berupa rataq atau qaran. Illat yang terdapat dari penyakit rataq dan qaran adalah suatu bentuk penyakit atau cacat yang dapat menghalangi hubungan seksual, sebagaimana yang ditemukan pada penyakit vaginismus.

Dari penjelasan di atas dapat disimpulkan bahwa virginismus dapat dijadikan sebagai alasan perceraian menurut Kompilasi Hukum 
Islam. Begitu juga menurut fikih Syafi'iyah, virginismus dapat dijadikan alasan perceraian karna diqiyaskan kepada penyakit rataq dan qaran yang merupakan bagian dari aib atau penyakit yang mempunyai kemungkinan kecil untuk disembuhkan, dengan illat sama-sama menghalangi untuk terjadinya watha' (hubungan seks).

\section{Endnotes:}

1 Abu Zakaria, Mengawetkan Cinta kasih Suami Istri, Solo: CV. Aneka, 1997, Cet. Ke 7, h. 91

2 Bagi suami yang merasa kebutuhan seksnya tidak terpenuhi dapat disebabkan oleh istrinya vaginismus. Hawton Keith, Terapi Sek Suatu Petunjuk Praktis, Jakarta: Erlangga, 1993, Alih Bahasa Chandra dan Meita, h. 14

3 Carolina Clyton, Keputihan dan Infeksi jamur Kandida lain, Jakarta: Arcan, 1986, h. 89

4 Marzuki Umar Sa'bah, Sek dan Kita, Jakarta: Gema Insani, 1996, h. 94

5 Abdurrahman, Kompilasi Hukum Islam di Indonesia, Jakarta: akademika Presind0, 1992, h. 141

6 Syech Mahmout Saltut, Perbandingan Mazhab dalam Masalah Fikih, Jakarta: Bulan Bintang, tt., h. 211

7 Al-baijuri ‘Ala Ibnu Qasim al-Ghazali, Al-Bajuri, Indonesia: Maktabah dahlan, tt. Juz II, h. 115-117

8 Edwar R. Brace, Kamus Penuntun Populer Bahasa Kedokteran, Bandung: Angkasa Bandung, 1984, h. 359

Abu Zakaria, Op.Cit., h. 145

Koesnadi, Op.Cit., h. 86

Ibnu M. Rasyid, Mahligai Perkawinan, Pekalongan: CV. Bahagia, 1996, Cet. Ke-6, h. 152

Budi Handrianto dan Nana Mintarti, Op.Cit., h. 91

Marzuki Umar Sa'bah, Op.Cit, h. 135

Koesnadi, Loc.Cit

Naek L. Tobing, Seksual Pria, Jakarta: Erlangga, 1990, h. 17

Marzuki Umar Sa'bah, Op.Cit, h. 136

Budi Handrianto dan Nana Mintarti, Loc.Cit.

Abu Zakaria, Loc. Cit

Ibnu M. Rasyid, Op. Cit., h. 153

Lilian Yuwono, Problematika Seks, Jakarta: Archan, 1993, h. 33

Imam Muslim, Shoheh Muslim, Beirut: Darul Maktabah Alamiah, tt., Juz 1, h. 304

Naek L. Tobing, Seks dalam Perkawinan, Jakarta: Erlangga, 1989, h. 9

Naek L. Tobing, Seksual Pria, h. 10

Ibid., h. 11

Budi Handrianto dan Nana Mintarti, Op.Cit., h. 93

Abdurrahman, Kompilasi Hukum Islam di Indonesia, Jakarta: akademika Presindo, 1992, h. 141

27 Muhammad Ibn Idris Asy-Syafi'I, Al-Umm, Beirut: dar al-Fikri, tt., Juz III, h. 98

28 Muhammad Ibn Idris Asy-Syafi'I, Ibid., h. 277

29 Jalaluddin Mahally, Qulyubi wa Umairah, Tp. Maktabah Dar Ihya Al-Kutub Alarabiyah, tt., Juz III, h. 261-262 
30 Abdurrahman Al-Jaziri, Kitab Al-Fiqh 'ala Mazahib Al-Arba'ah, Beirit: Darul Fikri, 1969, Juz IV, h. 19

31 Wahbah Zuhaily, Al-Fiqh Islam wa Adillah, Damsik: dar Al-Fikri, 1989, h. 517

32 Imam M. Ismail Al-Kahlani, Subulus Salam, Indonesia: Maktabah dahlan, t.t, Juz III, h. 135

\section{DAFTAR PUSTAKA}

Abdurrahman. 1992. Kompilasi Hukum Islam di Indonesia. Jakarta: Akademika Presindo

Abu Zakaria. 1997. Mengawetkan Cinta kasih Suali Istri. Solo: CV. Aneka, Cet. Ke 7

Al-Ghazali, Al-Bajuri 'Ala Ibnu Qasim. t.th. Al-Bajuri. Indonesia: Maktabah Dahlan, Juz II

Al-Jaziri, Abdurrahman. 1969. Kitab Al-Fiqh 'ala Mazahib Al-Arba'ah. Beirit: Darul Fikri, Juz IV

Al-Kahlani, Imam M. Ismail. t.th. Subulus Salam, Indonesia: Maktabah Dahlan, Juz III

Al-Mahally, Jalaluddin.t.th. Qulyubi wa Umairah, Tp. Maktabah Dar Ihya Al-Kutub Al-

Al-Zuhaily, Wahbah. 1989. Al-Figh Islam wa Adillah, Damsik: Dar Al-Fikri

Asy-Syafi'i, Muhammad Ibn Idris. t.th., Al-Umm, Beirut: Dar al-Fikri alArabiyah, Juz III

Brace, Edwar R. 1984. Kamus Penuntun Populer Bahasa Kedokteran, Bandung: Angkasa Bandung

Clyton, Carolina. 1986. Keputihan dan Infeksi jamur Kandida Lain, Jakarta: Arcan

Ibnu M. Rasyid. 1996. Mahligai Perkawinan, Pekalongan: CV. Bahagia,Cet. Ke-6

Imam Muslim. t.th., Shoheh Muslim, Beirut: Darul Maktabah Alamiah, Juz 1

Keith, Hawton. 1993. Terapi Sek Suatu Petunjuk Praktis, Jakarta: Erlangga, Alih Bahasa Chandra dan Meita

Lilian Yuwono, 1993. Problematika Seks, Jakarta: Archan

Naek L. Tobing. 1990. Seksual Pria, Jakarta: Erlangga

Naek L. Tobing. 1989. Seks dalam Perkawinan, Jakarta: Erlangga 
Syaltut, Syech Mahmout. t.th. Perbandingan Mazhab dalam Masalah Fikih, Jakarta: Bulan Bintang

Umar Sa'bah, Marzuki. 1996. Seks dan Kita, Jakarta: Gema Insani Press 